\title{
Release of CGRP from mouse brainstem slices indicates central inhibitory effect of triptans and kynurenate
}

\author{
Charlotte Kageneck, Barbara E Nixdorf-Bergweiler, Karl Messlinger and Michael JM Fischer
}

\begin{abstract}
Background: CGRP is contained in a substantial proportion of unmyelinated trigeminal neurons innervating intracranial tissues. Previously, we have described a hemisected rodent scull preparation and later the intact trigeminal ganglion to measure stimulated CGRP release from trigeminal afferents.

Methods: Here, we establish a preparation for examining CGRP release from central trigeminal terminals using single fresh slices of the mouse medullary brainstem.

Results: Basal and stimulated amount of CGRP substantially exceeded the detection level. Experiments were designed as matched pairs of at least six brainstem slices per animal. Stimulation with high potassium induced calcium-dependent and reversible CGRP release. Capsaicin stimulation of TRPV1 provoked concentration-dependent CGRP release. The anti-migraine drug naratriptan did not inhibit capsaicin-induced CGRP release from peripheral terminals but inhibited the release from brainstem slices. The glutamate antagonist kynurenate showed a similar pattern of site-specific inhibition of CGRP release.

Conclusions: As observed earlier for other drugs used in the treatment of migraine this indicates that the central terminals in the spinal trigeminal nucleus may be the main site of action. The preparation allows evaluating the trigeminal brainstem as a pharmacological site of action.
\end{abstract}

Keywords: Headache; Migraine; Neuropeptide; Nociception; 5-HT receptor

\section{Background}

The neuropeptide calcitonin gene-related peptide (CGRP), a potent vasodilator in all mammals including humans, is found in a substantial percentage of trigeminal afferents. CGRP is released upon activation of peptidergic afferent neurons in animals [1] and also in humans, demonstrated by electrocoagulation of the trigeminal ganglion, where flushing of patients was correlated with elevated CGRP plasma levels [2]. Also trigeminal inflammation inside the blood brain barrier is sufficient to elevate venous CGRP outflow [3], but there is discussion regarding the functional significance of resting as well as elevated blood CGRP levels. Quantifying mass activation of primary sensory neurons via the release of expressed neuropeptides is an established experimental technique [4]. The neuropeptides are transported to all parts of the sensory neurons

\footnotetext{
* Correspondence: fischer@physiologie1.uni-erlangen.de

Institute of Physiology and Pathophysiology, University of

Erlangen-Nuremberg, Universitaetsstrasse, 91054 Erlangen, Germany
}

and are thus found not only in the cell body but also in the peripheral and central axons. Accordingly, CGRP release can be stimulated from these locations as previously shown throughout the body for peripheral projections of afferents [5], DRG neurons [6] and their central projections [7]. Various tissues innervated by trigeminal afferents, e.g. the tooth pulp, have been probed using CGRP release measurements [8]. For investigating the headacherelevant trigeminal system, we have previously established such a preparation for terminals in the dura mater of the hemisected rodent scull [9], and for the freshly dissected intact rodent trigeminal ganglion [10]. The mentioned preparations have been used to investigate functional aspects of the trigeminal system $[11,12]$. Compared to previous attempts to measure CGRP from the trigeminal brainstem, which have used at least one animal for a single data point, we present CGRP release from a single mouse trigeminal brainstem slice. The first synaptic relay site in the spinal trigeminal nucleus of the medullary brainstem 
is of particular interest, as it seems to be the key for the preferential action of CGRP and CGRP receptor antagonists [12-16]. Together with the CGRP release preparations described previously, this allows to investigate the effect of chemical stimuli and antagonists on trigeminal afferents at all possible sites of action. We employed this preparation to examine if there are site-specific mechanisms of action.

\section{Methods}

All procedures were performed according to the German guidelines and regulations of animal care and welfare and approved by the responsible Animal Care Authority of the local district government (Ansbach, Germany). Experiments were carried out in accordance with the European Communities Council Directive of 24 November 1986 (86/609/EEC). For brainstem slices, home bred C57BL/6 mice of both sexes, aged 9-25 days, were used due to sufficient preparation size and experience regarding the vitality of slices for electrophysiological experiments. Mice were decapitated during inhalation anesthesia with halothane or sevofluorane. The medullary brainstem was dissected and cut in ice-cold artificial cerebrospinal fluid (ACSF, in mM: $87 \mathrm{NaCl}, 2.5 \mathrm{KCl}, 0.5 \mathrm{CaCl}_{2}, 7 \mathrm{MgCl}_{2}, 1.25$ $\mathrm{NaH}_{2} \mathrm{PO}_{4}, 25 \mathrm{NaHCO}_{3}, 75$ sucrose and 30 D-glucose, $\mathrm{pH} 7.4$, saturated with $95 \% \mathrm{O}_{2}$ and $\left.5 \% \mathrm{CO}_{2}\right)$. After cutting serial transverse slices on a vibrating blade microtome (VT1000S or VT1200S, Leica Biosystems Nussloch GmbH), the sections were transferred into synthetic interstitial fluid (SIF, in mM: $107.8 \mathrm{NaCl}, 26.2 \mathrm{NaCO}_{3}, 9.64 \mathrm{Na}$-gluconate, 7.6 sucrose, 5.55 glucose, $3.48 \mathrm{KCl}, 1.67 \mathrm{NaH}_{2} \mathrm{PO}_{4}, 1.53$ $\mathrm{CaCl}_{2}$ and $0.69 \mathrm{MgSO}_{4}$ [17]. No difference was observed when slicing was performed in SIF instead of ACSF. Slices were cut within a range of $3 \mathrm{~mm}$, extending from cervical C2 segments to the rostral medullary brainstem (obex). Slices of $150 \mu \mathrm{m}$ appeared too fragile for the further experimental handling. Slices finally evaluated had a thickness within the range of 200-400 $\mu \mathrm{m}$; we recommend the upper half of this range. All slices were captured and transferred on a micromesh into a 96 well plate filled with SIF. The plate was placed in a $37^{\circ} \mathrm{C}$ bath for $30 \mathrm{~min}$ before the experimental stimulation. Mouse trigeminal ganglia and mouse hemisected sculls were prepared as previously described $[9,10]$.

Every brainstem slice was placed in a separate well and held at $37^{\circ} \mathrm{C}$. An incubation step consisted of adding $125 \mu \mathrm{l}$ carbogen-saturated SIF for $5 \mathrm{~min}$, at the end of this period acquisition of $100 \mu \mathrm{l}$ to determine CGRP content, removal of the remaining fluid, and a single wash with $125 \mu \mathrm{l}$ before adding fluid for the next incubation period. In the first two steps basal CGRP release was determined, in the third step the preparations were stimulated, the fourth step was used to evaluate recovery. Adjacent slices were used for the different experimental groups to allow matched-pairs comparison. This matched-pairs comparison reduces the statistical effect of inter-day variation of the EIA. A maximum of eight slices per animal was evaluated. The increase in CGRP release evoked in pairs of identically stimulated adjacent slices was correlated (Capsaicin $100 \mathrm{nM}, \mathrm{R}=0.64, \mathrm{p}=0.004, \mathrm{n}=19$ pairs from 11 animals). Therefore, the provided $\mathrm{n}$ indicates the number of slices. However, all presented experimental groups contain at least four independent animals and days. The CGRP content of the samples was determined using a commercial sandwich enzyme immune assay kit for human CGRP, which is crossreactive to mouse CGRP (SPIbio, France). This technique was previously published in detail [18]. Briefly, the samples are incubated with precoated capture and acetylcholin-esterase-conjugated tracer antibody overnight, washed and developed with Ellman's reagent, quantified at $405 \mathrm{~nm}$. The assay has a 'Limit of detection' of $5 \mathrm{pg} / \mathrm{ml}$ for CGRP, all values measured in this study were substantially above this level. CGRP content of brainstem slices was measured as described previously [10]. Briefly, preparations were sliced in calcium-free SIF and homogenized using an Ultra-Turrax T8 (IKA Works, Staufen, Germany), preceded and followed by a $10 \mathrm{~min}$ period in $1 \mathrm{ml}$ of $2 \mathrm{M}$ acetic acid at $95^{\circ} \mathrm{C}$. The suspension was centrifuged for $30 \mathrm{~min}$ at 10,000 g. The CGRP content of the supernatant was measured after titration to neutral pH. Blank and CGRP-spiked controls showed that the titrated acetic acid and the resulting 1330 mosmol for overnight antibody incubation had no effect on the CGRP measurements. In separate experiments with an identical experimental protocol, $100 \mu \mathrm{l}$ of elution fluid was used to determine LDH activity with the LDH Cytotoxicity Assay Kit (Cayman, Ann Arbor, MI, USA) as described by the manufacturer.

The extracellular solution with $\mathrm{KCl} 40 \mathrm{mM}$ was generated by isoosmolar substitution of sodium chloride by potassium chloride. Capsaicin and Kynurenate was obtained from Sigma-Aldrich (St. Louis, MO, USA), N-(4-t-Butylphenyl)-4-(3-chloropyridin-2-yl)tetrahydropyrazine-1(2H)carboxamide (BCTC) from Biotrend (Cologne, Germany). Stock solutions were prepared in ethanol and freshly diluted for the experiment, the resulting final ethanol concentration was $\leq 0.01 \%$. Naratriptan was obtained from Glaxo Wellcome (London, United Kingdom) and freshly diluted in SIF.

Statistical analysis was performed with STATISTICA (StatSoft, Tulsa, OK). Subsequent measurements within the same slices were tested with the Wilcoxon matched pairs test. The stimulation-induced changes of CGRP release between adjacent slices of different experimental groups were also compared with the Wilcoxon matched pairs test. Two-way analysis of variance was used to evaluate two or more groups at two or more time points. A concentration-response profile was fitted a Boltzmann 
function with a baseline fixed to zero in Origin (OriginLab, Massachusetts). Panels were compiled in Origin and arranged in CorelDraw (Corel, Ontario). Data are presented as mean \pm SEM, $\mathrm{p}<0.05$ was considered significant.

\section{Results}

Basal CGRP release from mouse brainstem slices within 5 min was $25 \pm 1 \mathrm{pg} / \mathrm{ml}(\mathrm{n}=133$, slices of $300-400 \mu \mathrm{m}$, pooled from the first $5 \mathrm{~min})$. CGRP release was not correlated to the thickness in the tested range of 200-400 $\mu \mathrm{m}$ ( $\mathrm{R}=0.01$, product-momentum correlation). Compared to baseline, depolarization by potassium chloride $40 \mathrm{mM}$ increased CGRP release by $109 \pm 23 \mathrm{pg} / \mathrm{ml}(\mathrm{p}=0.003, \mathrm{n}=11$, Wilcoxon). This recovered by $84 \%$ within the subsequent $5 \mathrm{~min}$. No potassium-stimulated CGRP release was observed in the absence of extracellular calcium $(p=0.21$, $\mathrm{n}=10$, Wilcoxon, + EGTA $5 \mathrm{mM}$, Figure 1A). Capsaicin $100 \mathrm{nM}$ increased CGRP release from $35 \pm 6 \mathrm{pg} / \mathrm{ml}$ to $221 \pm 33 \mathrm{pg} / \mathrm{ml}$ ( $\mathrm{p}=0.003, \mathrm{n}=11$, Wilcoxon). The quick recovery led us to investigate repetitive stimulation of the same sample. A second stimulation with capsaicin $100 \mathrm{nM}$ $40 \mathrm{~min}$ later increased CGRP by $56 \pm 18 \mathrm{pg} / \mathrm{ml}(\mathrm{p}=0.008)$, which is $30 \%$ of the first stimulation (Figure 1B). Addition of the TRPV1 antagonist BCTC $100 \mathrm{nM}$ after $5 \mathrm{~min}$ had no effect on its own but abolished the capsaicin-evoked response compared to experiments without BCTC $(\mathrm{p}=0.33$, $\mathrm{n}=8$, Wilcoxon). Acidic SIF ( $\mathrm{pH} 5.8$ ) also increased CGRP release by $26 \mathrm{pg} / \mathrm{ml}(\mathrm{p}=0.004, \mathrm{n}=11$, Wilcoxon, Figure $1 C)$, but less compared to capsaicin, which was therefore preferred for further experiments. The vitality of the tissue was probed by quantifying extracellular LDH activity. The samples were subjected to four consecutive 5-min elution steps in SIF, a constant LDH activity was observed throughout $(\mathrm{n}=8)$. In four of these samples capsaicin $100 \mathrm{nM}$ was added in the third period, which did not alter LDH activity. As positive control, Triton X-100 1\% added to the fifth period increased LDH activity substantially (ANOVA, $F_{(1,6)}=24.6, p=0.003$, Figure 1D). No difference was observed in samples previously exposed to capsaicin compared to those treated without capsaicin ( $\mathrm{p}=0.60$, HSD-post-hoc test). We thus measured LDH activity at periods of 1, 2, 4 and $8 \mathrm{~h}$ after preparation and observed no increase (15 min of sampling in SIF, $\mathrm{n}=3$, data not shown).

Capsaicin stimulation was tested in the range of 10-1000 nM. A significant increase in CGRP release was observed for capsaicin doses of $100 \mathrm{nM}$ and above $(\mathrm{p}=0.009$, $\mathrm{p}=0.028$ and $\mathrm{p}=0.012, \mathrm{n}=6-15$, Wilcoxon). Concentrationdependent CGRP release by capsaicin had an $\mathrm{EC}_{50}$ of $88 \pm 5$ $\mathrm{nM}$ (Figure 2). A $400 \mu \mathrm{m}$ thick mouse brainstem slice had a wet weight of $3.7 \pm 0.5 \mathrm{mg}$ and a CGRP content of $1217 \pm 180 \mathrm{ng} / \mathrm{g}(\mathrm{n}=5)$. Thus, capsaicin $1 \mu \mathrm{M}$ released about $0.6 \%$ of the total CGRP content within five minutes.

The effect of naratriptan on CGRP release from the peripheral projections, cell bodies and central projections of trigeminal neurons was tested employing a preparation of the dura in the hemisected skull, the isolated intact trigeminal ganglion and brainstem slices from mice. Capsaicin induced CGRP release of $248 \pm 42 \mathrm{pg} / \mathrm{ml}$ from the hemisected scull, $33 \pm 6 \mathrm{pg} / \mathrm{ml}$ from the isolated intact trigeminal ganglion and $363 \pm 80 \mathrm{pg} / \mathrm{ml}$ from brainstem slices $(\mathrm{p}=0.002, \mathrm{p}=0.002$ and $\mathrm{p}=0.003, \mathrm{n}=12-13$, Wilcoxon, Figure 3). Application of naratriptan $1 \mu \mathrm{M}$ alone did not alter basal CGRP release compared to controls in all three preparations. In the hemisected skull the presence of naratriptan $1 \mu \mathrm{M}$ did not alter capsaicinevoked CGRP release ( $\mathrm{p}=0.43, \mathrm{n}=12$, Wilcoxon). In the trigeminal ganglion, evoked CGRP release in the presence of naratriptan was $68 \%$ of the control $(\mathrm{p}=0.09, \mathrm{n}=12$, Wilcoxon) and in the brainstem slices naratriptan reduced the evoked CGRP release to 55\% ( $\mathrm{p}=0.047, \mathrm{n}=11$, Wilcoxon). In the presence of naratriptan $0.1 \mu \mathrm{M}$ CGRP release was $98 \%$ of controls ( $\mathrm{p}=0.50, \mathrm{n}=10$, Wilcoxon). Naratriptan $10 \mu \mathrm{M}$ released $107 \%$ compared to control experiments $(n=5)$. The pattern of the remaining CGRP release in the presence of naratriptan $1 \mu \mathrm{M}$ of the present study is overlayed with previous results in Figure 4 [11].

In a similar fashion, the effect of the glutamate receptor antagonist kynurenate on CGRP release was probed at different sites within the mouse trigeminal system. Kynurenate was applied in the second step and did not alter basal CGRP release in all three preparations. In the hemisected skull preparation, capsaicin-stimulated CGRP release from the dura mater was not inhibited by kynurenate $2 \mathrm{mM}$ (136\% of controls, Figure 5). Capsaicin-stimulated CGRP release from isolated intact trigeminal ganglia in the presence of kynurenate $2 \mathrm{mM}$ was $70 \%$ of the controls $(\mathrm{p}=0.07, \mathrm{n}=8$, Wilcoxon). However, capsaicin-stimulated CGRP release from brainstem slices was significantly reduced by kynurenate $2 \mathrm{mM}$ to $46 \%$ of the controls $(\mathrm{p}=0.036, \mathrm{n}=15$, Wilcoxon). In the presence of kynurenate $0.2 \mathrm{mM}$, CGRP release was $71 \%$ of the controls ( $\mathrm{p}=0.09, \mathrm{n}=11$, Wilcoxon), kynurenate $20 \mathrm{mM}$ released $135 \%$ of the controls $(\mathrm{n}=4)$.

\section{Discussion}

We have established a preparation in which we assessed stimulation-induced, reversible and robust CGRP release from single mouse medullary brainstem slices. Naratriptan and kynurenate inhibited capsaicin-induced CGRP release from the medullary brainstem but not from peripheral terminals innervating the dura mater.

Shortly after CGRP was discovered [19], its presence in primary sensory afferents [20], and in particular trigeminal neurons was described [21]. Compared with other neuropeptides, CGRP is the most widely expressed neuropeptide in sensory afferents [22]. CGRP is produced by a large proportion of small- and intermediate-sized trigeminal afferents and transported from the somata to the peripheral and the central terminals. In the spinal trigeminal nucleus 


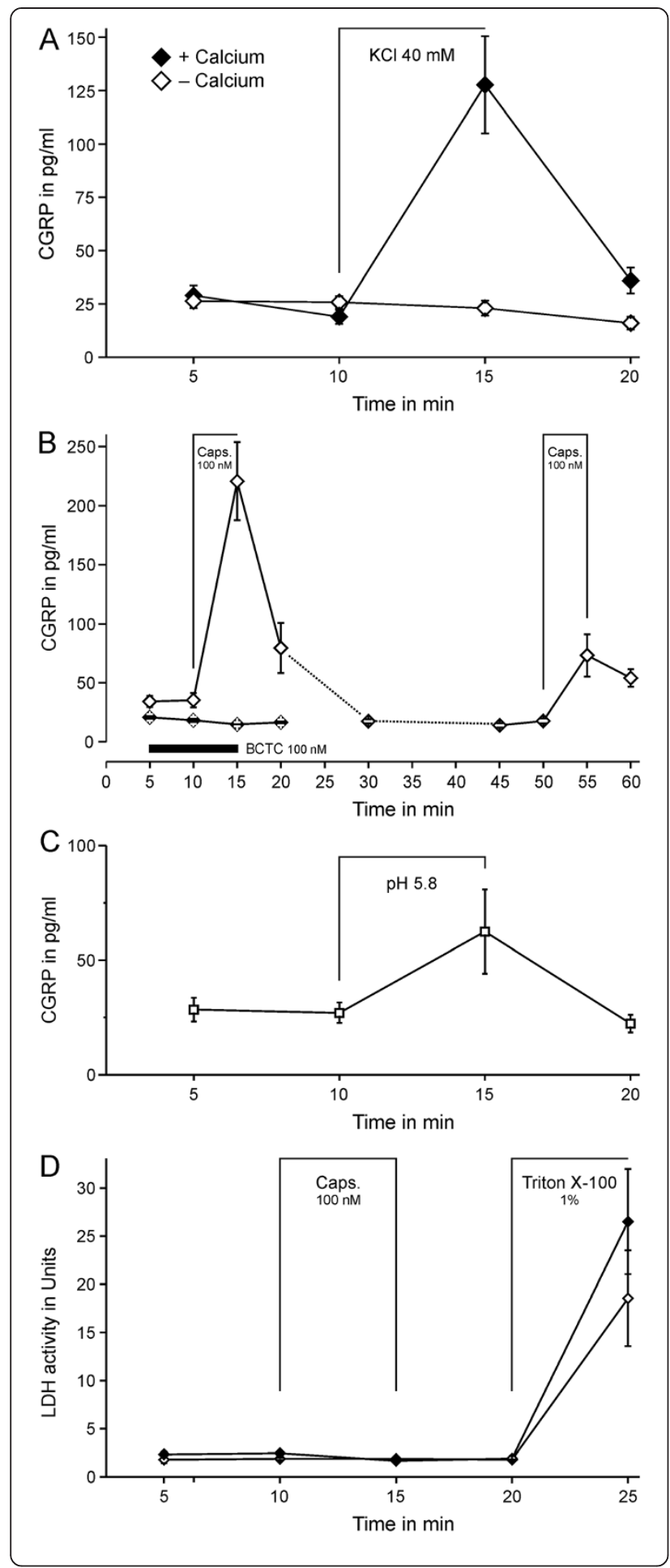

Figure 1 Stimulated calcitonin gene-related peptide (CGRP) release from single mouse brainstem slices. A) Potassiuminduced depolarisation for 5 min induced CGRP release in a reversible manner $(n=11)$. In adjacent slices, no CGRP release was observed by the same stimulation in the absence of calcium. B) Capsaicin-induced stimulation of CGRP release. The second stimulation induced less CGRP release $(n=11)$. In the presence of the TRPV1 antagonist BCTC $100 \mathrm{nM}$ (duration indicated by black bar, closed symbols, $n=8$ ) capsaicin-induced release was abolished. C) Acidic extracellular solution of pH 5.8 stimulated CGRP release from brainstem slices $(n=11)$. D) LDH-activity assay from brainstem slices, treated as described above. In the eluate, a low and constant LDH activity was observed throughout, treatment with capsaicin did not alter LDH activity. Triton-X 100 employed as a positive control increased LDH activity in all samples $\left(^{*}\right)$; there was no difference between the brainstem slices previously treated with capsaicin $100 \mathrm{nM}$ (filled symbols) and those without (open symbols, $n=4$ each). No increase in $\mathrm{LDH}$ activity was observed $1,2,4$ and $8 \mathrm{~h}$ after preparation $(\mathrm{n}=3$, not shown). Data are mean \pm SEM.

(medullary dorsal horn), which is the central projection site of most of nociceptive trigeminal afferents, CGRP immunoreactivity is found preferably in the superficial layers I-II [23]. Dorsal rhizotomy or neonatal capsaicin treatment depleted spinal CGRP content, which indicates the

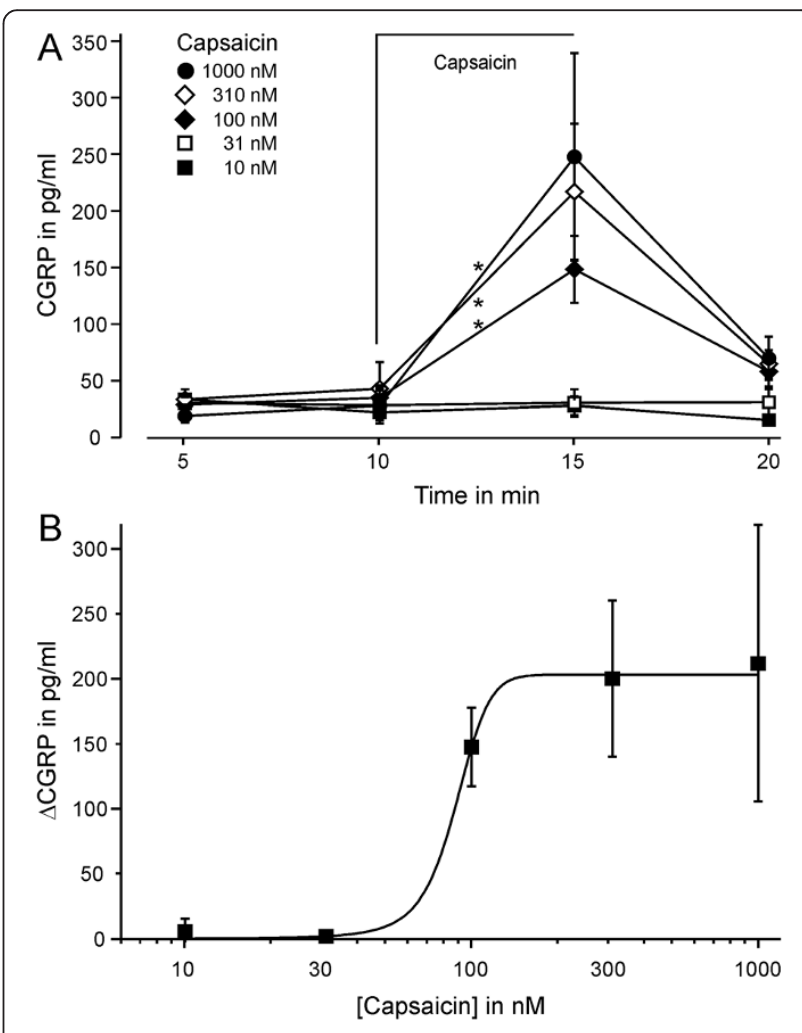

Figure 2 Concentration-dependence of capsaicin-induced CGRP release. A) Time course of the experiments, showing the concentration-dependent increase in CGRP for capsaicin $\geq 100 \mathrm{nM}$, which largely recovered within the subsequent $5 \mathrm{~min}(n=6-14)$. B) For the increase in CGRP release ( $\triangle C G R P)$, calculated between the values at 10 and $15 \mathrm{~min}$, a fitted dose-response function had an $\mathrm{EC}_{50}$ of $88 \pm 5 \mathrm{nM}$. Data are mean \pm SEM. ${ }^{*} \mathrm{p}<0.05$. 


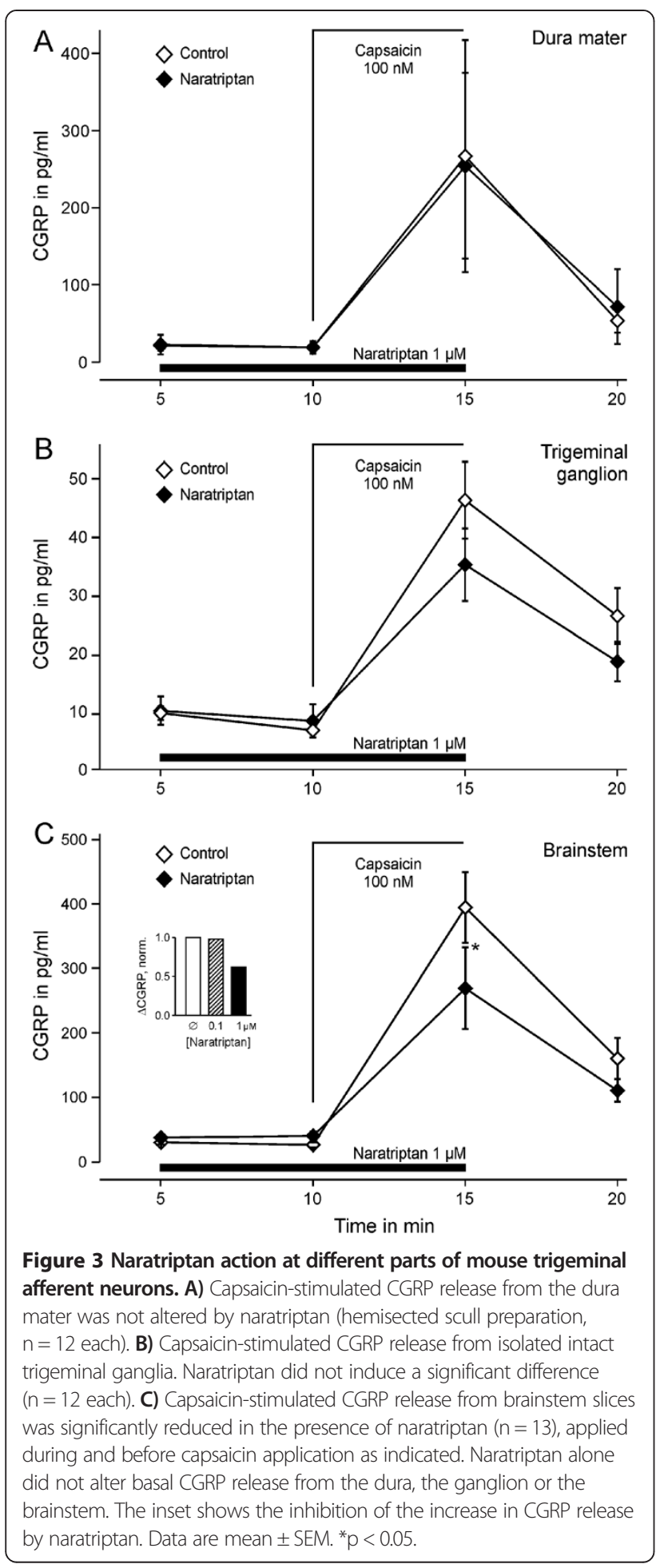

exclusive presence in primary afferents $[24,25]$. This is important for the presented preparation, in which afferent fibers comprise a small minority of the tissue. Despite the large number of cell types contained in the slices, specificity is not only gained by sampling CGRP-containing neurons, but also by stimulation with subpopulation-specific

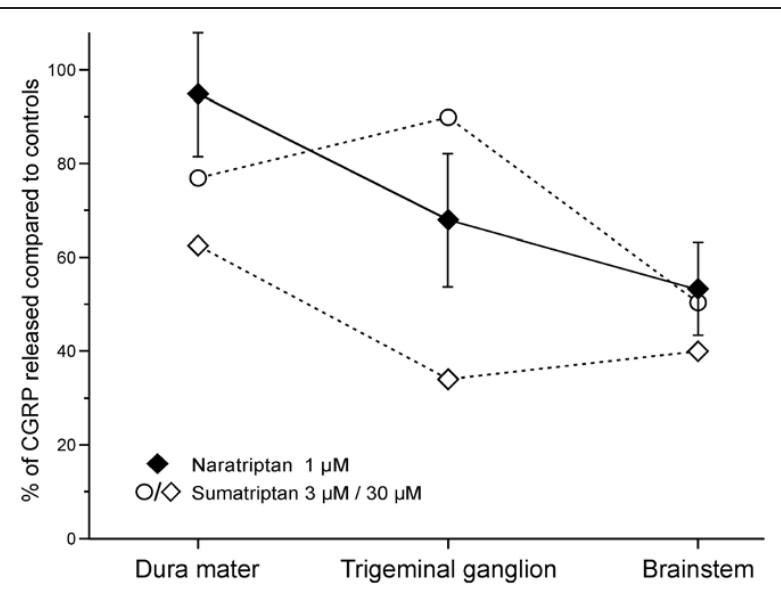

Figure 4 Triptans inhibit CGRP release in a location-dependent manner. Open symbols show the inhibition of potassium-stimulated CGRP release by sumatriptan (data taken from [11]). Closed symbols represent the inhibition of capsaicin-induced CGRP release by naratriptan observed in the current study. There is a correlation between the site of application and percent of inhibition by naratriptan $(R=-0.48, p=0.004$, Spearman correlation). Data are mean \pm SEM.

agonists like capsaicin. Stimulation with acidic $\mathrm{pH}$, which typically involves TRPV1 [26], led only to a limited release of CGRP compared to capsaicin.

\section{Comparison to previously published preparations}

All previous studies investigating CGRP release have used brainstem tissue of at least one animal [11,12,27], some even multiple animals [28]. In contrast, the presented preparation uses less brainstem tissue with a smaller volume to measure a robust signal. This allowed performing multiple experiments from slices of a single animal, including a matched pairs design with adjacent slices. In contrast, compared to CGRP release from lumbar spinal cord cut by a tissue chopper into small pieces [29], the method presented here is less disruptive. A limitation of the method is the restriction to CGRPexpressing neurons; no similar index substance is available for non-peptidergic neurons. In conclusion, several advantages qualify this preparation to screen effects on the activation of peptidergic central trigeminal terminals. Certainly, the brainstem slices show undiminished vitality throughout the experiments, which is confirmed by the employed LDH assay. Brainstem slices of similar thickness prepared with a similar protocol for electrophysiological recordings remain usable for several hours.

Capsaicin has been shown to stimulate CGRP release from rat spinal cord slices using a radioimmunoassay $[7,30]$. Immunohistochemistry has been used to show the release of neuropeptides by depletion [31], but this procedure requires excessive trigeminal ganglion stimulation to generate any change in the trigeminal nucleus. This is not surprising as there might be reuptake, and in 

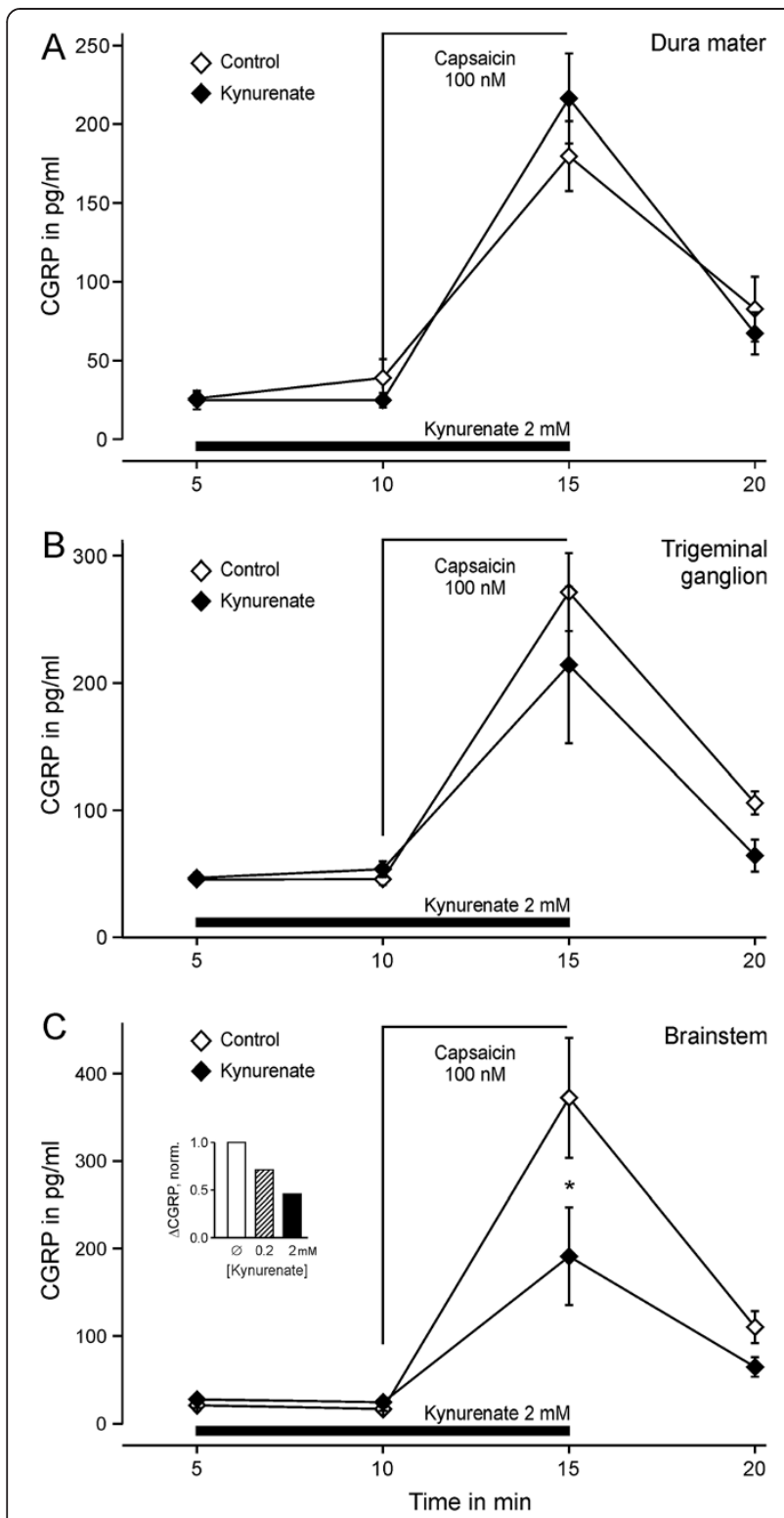

Figure 5 Kynurenate action at different parts of mouse

trigeminal afferent neurons. A) Capsaicin-stimulated CGRP release from the dura mater was not altered by kynurenate (hemisected scull preparation, $\mathrm{n}=8$ each). B) Capsaicin-stimulated CGRP release from isolated intact trigeminal ganglia. Kynurenate did not induce a significant difference $(n=8)$. C) Capsaicin-stimulated CGRP release from brainstem slices was significantly reduced in the presence of kynurenate $2 \mathrm{mM}(n=15)$, applied during and before capsaicin application as indicated. Kynurenate alone did not alter basal CGRP release from the dura, the ganglion or the brainstem. Concentrationdependent inhibition of the increase in CGRP release by kynurenate is shown in the inset. Data are mean \pm SEM. ${ }^{*} p<0.05$.

our hands a strong stimulation for five minutes only releases a small fraction of the neuropeptide content. Microprobes have been used to detect the release of neuropeptides such as substance $P[32,33]$. This semiquantitative method with high sensitivity and spatial resolution has occasionally been employed for CGRP release measurements but is limited by reliable fixation of CGRP antibodies to the glass probes [34].

\section{Practical considerations}

We initially varied slice thickness to investigate the amount of required tissue. Within the investigated range of 200-400 $\mu \mathrm{m}$, no association of basal or stimulated CGRP release to slice thickness was observed. As a result, we considered it acceptable to pool the data from different slice thicknesses. Thinner slices $(150 \mu \mathrm{m})$ were fragile and difficult to handle imposing a lower limit. Tissue poses some diffusion barrier as a function of molecular weight and size; in our preparation the 37 amino acid large CGRP molecule can be expected to diffuse slower than the solutions containing the pharmacological substances. The distance of released CGRP to the cutting surface is less than to the dorsal surface of the brainstem, so we assume that direct diffusion of CGRP from the cut surface has the largest contribution to the total release. This is in line with the observation that released CGRP does not vary with slice thickness. Various duration of the single steps have been used in the literature. We have previously observed a positive association between duration and CGRP content, indicating an ongoing release. Based on the signal, a range of $2-10 \mathrm{~min}$ seems practical, a period of $5 \mathrm{~min}$ was chosen for the present study as this was the most common sampling time used previously. The presented release from brainstem slices allows choosing the region of interest. Our variation of slice thickness and the lack of precise histology-based allocation for every used slice did not allow generating a histogram of CGRP release reflecting the position in cranio-caudal direction. It may be assumed that there is an association with the density of CGRP, which has been investigated down to the $\mathrm{C} 1$ level with much thinner slices before [35]. In the case of capsaicin stimulation this also relies on the assumption that the overlap between the capsaicin receptor TRPV1 and CGRP does not vary with the position.

Activation of neurons by a nociceptive-specific agonist like capsaicin activates a smaller population of neurons compared to the generally depolarizing potassium chloride. Nevertheless the amount of CGRP released after capsaicin was higher than after $\mathrm{KCl}$, which argues for a higher or prolonged rise of intracellular free calcium upon activation of TRPV1 receptor channels. The concentration of potassium $40 \mathrm{mM}$ was chosen based on results from other preparations, sufficient depolarization for admittance of calcium occurs around potassium $15 \mathrm{mM}$, a plateau of activation is typically observed at potassium $80 \mathrm{mM}$. In case the investigation of knockout mice is not an issue, the higher expression of CGRP in rats might favor these for the presented approach. 


\section{Differential triptan effects}

Different triptans and selective agonists for the 5-HT1 receptor subtypes have been investigated in the trigeminal system [11]. Aggregating the results of both applied sumatriptan concentrations used in their study reveals a similar pattern as we observed for naratriptan; the inhibition at the central site is more prominent compared to the peripheral site. This might have been obfuscated by the variation at the trigeminal ganglion, as this has the smallest signal of the three preparations. Taking the average of both sumatriptan doses fits our results with naratriptan well (Figure 4). Naratriptan has an $\mathrm{EC}_{50}$ below $100 \mathrm{nM}$ on both $5 \mathrm{HT}_{1 \mathrm{~B}}$ and $5-\mathrm{HT}_{1 \mathrm{D}}$ receptors [36]. $5-\mathrm{HT}_{1 \mathrm{~B}}$ and $5-\mathrm{HT}_{1 \mathrm{D}}$ receptors are present in more than $80 \%$ of human trigeminal ganglion neurons and the majority of CGRP-containing cells are positive for both receptors [37]; similar expression and colocalization was observed in rats [38]. The molecular mechanism of the triptan action downstream of $5-\mathrm{HT}$ receptors is not fully understood, but at least it seems to be comprised of several independent effects including the inhibition of voltage-gated sodium channels, suppression of voltagegated calcium currents and a hyperpolarizing shift in the voltage-dependence of potassium currents [39].

\section{Differential kynurenate effects}

Effects of the endogenously occurring kynurenate are biochemically linked to 5 -HT, as both are synthesized from tryptophan, and both pathways interact [40-43]. Kynurenate is an antagonist of NMDA, AMPA and kainate receptors [44], and therefore frequently used in experimental models to investigate ionotropic glutamate receptors effects. The concentration of $2 \mathrm{mM}$ kynurenate is frequently used; a sensitization of capsaicininduced release observed at $20 \mathrm{mM}$ occurs probably through a different target. Glutamate receptor inhibition has been suggested as potential therapeutic mechanism for headaches. Activity induced by electrical stimulation of the trigeminal ganglion, resulting in increased c-fos immunoreactivity in the caudal trigeminal nucleus, was almost abolished by kynurenate infusion in rats [45]. Kynurenate was shown to inhibit the delayed trigeminal activation induced by glyceroltrinitrate, using CamKII or cFos as a marker $[46,47]$. Combined inhibition of AMPA and kainate receptors was effective as treatment for migraine [48]. All ionotropic glutamate receptors were found in the superficial laminae of the trigeminal nucleus [49]. Subunits of the NMDA receptor were found on about $20 \%$ of rat trigeminal sensory neurons [50,51], also AMPA, kainate and metabotropic glutamate mGluR5 receptors were found in the rat trigeminal ganglion $[52,53]$. The somata of rat trigeminal sensory neurons were shown to respond to stimulation with AMPA, NMDA, kainate and mGluR agonists [54]. For NMDA receptors, sensitization of TRPV1 via phosphorylation was evidenced as potential downstream mechanism in trigeminal sensory neurons [55]. Since the central terminals of primary afferents are the most important if not the only source for CGRP in the medulla, it is likely that presynaptic glutamate receptors are responsible for the glutamate effect. In the presented experiments, capsaicin-released glutamate might contribute to the calcium-dependent CGRP release via presynaptic glutamatergic autoreceptors [56]. The activation of calciumpermeable NMDA receptors could directly admit calcium to central afferent terminals, providing a secondary fraction of calcium in addition to the calcium entering via TRPV1 upon capsaicin stimulation. At the central terminals this contribution seems significant, given that kynurenate blocked about half of the capsaicinstimulated release in brainstem slices. It should be noted that kynurenate could exert its effects through other targets than glutamate receptors, e.g. the G-protein-coupled receptor GPR35 or alpha7 nicotinic acetylcholine [57-60]. The production of glutamate receptors in the trigeminal ganglion suggests a transport of glutamate receptors peripherally and centrally. Since kynurenate did not inhibit CGRP release in the dura mater, it might by hypothesized that the required cascades are only fully assembled in presynaptic terminals, but not complete at other parts of the trigeminal afferents.

Administration of CGRP has facilitated glutamatergic transmission [16]. The basis for this cooperative effect of CGRP and glutamate is not clear. We speculate that CGRP itself might facilitate glutamate release, which would fit to the immunohistochemical observation that CGRP receptor components are localized presynaptically on primary afferent terminals, but not on second order neuron cell bodies in the Sp5C [61].

\section{Conclusions}

This article presents a CGRP release preparation from mouse brainstem slices and therefore extends the release preparations reported by the group previously. A triptan and a glutamate receptor antagonist both inhibited the CGRP release from the brainstem, whereas there was only a tendency towards inhibition in the trigeminal ganglion and no effect in the dura mater. This shows that the three preparations allow investigating the site of action throughout the first neuron of the trigeminal system.

\section{Abbreviations}

ACSF: Artificial cerebrospinal fluid; CGRP: Calcitonin gene-related peptide; SIF: Synthetic interstitial fluid; TRPV1: Transient receptor potential, vanilloid type 1.

\section{Competing interests}

The study received support by the Emerging Fields Initiative of the FriedrichAlexander-University. The authors declare no conflict of interest. 


\section{Authors' contributions}

CK performed the experiments and wrote the manuscript; the present work was performed to obtain the degree 'Dr. med.' at the 'Friedrich-Alexander Universität Erlangen-Nürnberg (FAU)'. BS-B sliced brainstems, KM wrote the manuscript and supervised the project. MJMF designed the study, analyzed the data and wrote the manuscript. All authors read and approved the final manuscript.

\section{Acknowledgements}

We like to thank Hans van Brederode for experimental advice, Christian Alzheimer for the use of the tissue slicer, Maria Schulte, Birgit Vogler, Annette Kuhn and Susanne Haux-Oertel for technical assistance.

\section{Received: 17 December 2013 Accepted: 1 February 2014}

\section{Published: 8 February 2014}

\section{References}

1. Brain SD, Cox HM (2006) Neuropeptides and their receptors: innovative science providing novel therapeutic targets. Br J Pharmacol 147(Suppl 1): S202-S211

2. Goadsby PJ, Edvinsson L, Ekman R (1988) Release of vasoactive peptides in the extracerebral circulation of humans and the cat during activation of the trigeminovascular system. Ann Neurol 23:193-196

3. Hoffmann J, Wecker S, Neeb L, Dirnagl U, Reuter U (2012) Primary trigeminal afferents are the main source for stimulus-induced CGRP release into jugular vein blood and CSF. Cephalalgia 32:659-667

4. Levine JD, Fields HL, Basbaum Al (1993) Peptides and the primary afferent nociceptor. J Neurosci 13:2273-2286

5. Franco-Cereceda A, Saria A, Lundberg JM (1987) Ischaemia and changes in contractility induce release of calcitonin gene-related peptide but not neuropeptide $Y$ from the isolated perfused guinea-pig heart. Acta Physiol Scand 131:319-320

6. Perney TM, Hirning LD, Leeman SE, Miller RJ (1986) Multiple calcium channels mediate neurotransmitter release from peripheral neurons. Proc Natl Acad Sci USA 83:6656-6659

7. Saria A, Gamse R, Petermann J, Fischer JA, Theodorsson-Norheim E, Lundberg JM (1986) Simultaneous release of several tachykinins and calcitonin gene-related peptide from rat spinal cord slices. Neurosci Lett 63:310-314

8. Loyd DR, Sun XX, Locke EE, Salas MM, Hargreaves KM (2012) Sex differences in serotonin enhancement of capsaicin-evoked calcitonin gene-related peptide release from human dental pulp. Pain 153:2061-2067

9. Ebersberger A, Averbeck B, Messlinger K, Reeh PW (1999) Release of substance $P$, calcitonin gene-related peptide and prostaglandin E2 from rat dura mater encephali following electrical and chemical stimulation in vitro. Neuroscience 89:901-907

10. Eberhardt M, Hoffmann T, Sauer SK, Messlinger K, Reeh PW, Fischer MJ (2008) Calcitonin gene-related peptide release from intact isolated dorsal root and trigeminal ganglia. Neuropeptides 42:311-317

11. Amrutkar DV, Ploug KB, Hay-Schmidt A, Porreca F, Olesen J, Jansen-Olesen I (2012) mRNA expression of 5-hydroxytryptamine 1B, 1D, and $1 \mathrm{~F}$ receptors and their role in controlling the release of calcitonin gene-related peptide in the rat trigeminovascular system. Pain 153:830-838

12. Tringali G, Greco MC, Capuano A, Guerriero G, Curro D, Navarra P (2012) Flupirtine inhibits calcitonin-gene related peptide release from rat brainstem in vitro. Neurosci Lett 506:332-335

13. Fischer MJ, Koulchitsky S, Messlinger K (2005) The nonpeptide calcitonin gene-related peptide receptor antagonist BIBN4096BS lowers the activity of neurons with meningeal input in the rat spinal trigeminal nucleus. J Neurosci 25:5877-5883

14. Levy D, Burstein R, Strassman AM (2005) Calcitonin gene-related peptide does not excite or sensitize meningeal nociceptors: implications for the pathophysiology of migraine. Ann Neurol 58:698-705

15. Sixt ML, Messlinger K, Fischer MJ (2009) Calcitonin gene-related peptide receptor antagonist olcegepant acts in the spinal trigeminal nucleus. Brain 132:3134-3141

16. Storer RJ, Akerman S, Goadsby PJ (2004) Calcitonin gene-related peptide (CGRP) modulates nociceptive trigeminovascular transmission in the cat. Br J Pharmacol 142:1171-1181

17. Bretag AH (1969) Synthetic interstitial fluid for isolated mammalian tissue. Life Sci 8:319-329
18. Averbeck B, Reeh PW (2001) Interactions of inflammatory mediators stimulating release of calcitonin gene-related peptide, substance $P$ and prostaglandin E(2) from isolated rat skin. Neuropharmacology 40:416-423

19. Amara SG, Jonas V, Rosenfeld MG, Ong ES, Evans RM (1982) Alternative RNA processing in calcitonin gene expression generates mRNAs encoding different polypeptide products. Nature 298:240-244

20. Rosenfeld MG, Mermod JJ, Amara SG, Swanson LW, Sawchenko PE, Rivier J, Vale WW, Evans RM (1983) Production of a novel neuropeptide encoded by the calcitonin gene via tissue-specific RNA processing. Nature 304:129-135

21. Uddman R, Edvinsson L, Ekman R, Kingman T, McCulloch J (1985) Innervation of the feline cerebral vasculature by nerve fibers containing calcitonin gene-related peptide: trigeminal origin and co-existence with substance P. Neurosci Lett 62:131-136

22. Ju G, Hokfelt T, Brodin E, Fahrenkrug J, Fischer JA, Frey P, Elde RP, Brown JC (1987) Primary sensory neurons of the rat showing calcitonin gene-related peptide immunoreactivity and their relation to substance $\mathrm{P}$-, somatostatingalanin-, vasoactive intestinal polypeptide- and cholecystokininimmunoreactive ganglion cells. Cell Tissue Res 247:417-431

23. Uddman R, Tajti J, Hou M, Sundler F, Edvinsson L (2002) Neuropeptide expression in the human trigeminal nucleus caudalis and in the cervical spinal cord C1 and C2. Cephalalgia 22:112-116

24. McNeill DL, Chung K, Carlton SM, Coggeshall RE (1988) Calcitonin generelated peptide immunostained axons provide evidence for fine primary afferent fibers in the dorsal and dorsolateral funiculi of the rat spinal cord. J Comp Neurol 272:303-308

25. Tuchscherer MM, Seybold VS (1989) A quantitative study of the coexistence of peptides in varicosities within the superficial laminae of the dorsal horn of the rat spinal cord. J Neurosci 9:195-205

26. Fischer MJ, Reeh PW, Sauer SK (2003) Proton-induced calcitonin generelated peptide release from rat sciatic nerve axons, in vitro, involving TRPV1. Eur J Neurosci 18:803-810

27. Capuano A, Curro D, Navarra P, Tringali G (2011) Cortistatin modulates calcitonin gene-related peptide release from neuronal tissues of rat. Comparison with somatostatin. Peptides 32:138-143

28. Jenkins DW, Langmead CJ, Parsons AA, Strijbos PJ (2004) Regulation of calcitonin gene-related peptide release from rat trigeminal nucleus caudalis slices in vitro. Neurosci Lett 366:241-244

29. Garry MG, Hargreaves KM (1992) Enhanced release of immunoreactive CGRP and substance $P$ from spinal dorsal horn slices occurs during carrageenan inflammation. Brain Res 582:139-142

30. Nanayama T, Kuraishi Y, Ohno H, Satoh M (1989) Capsaicin-induced release of calcitonin gene-related peptide from dorsal horn slices is enhanced in adjuvant arthritic rats. Neurosci Res 6:569-572

31. Samsam M, Covenas R, Ahangari R, Yajeya J, Narvaez JA, Tramu G (1999) Alterations in neurokinin A-, substance $\mathrm{P}$ - and calcitonin gene-related peptide immunoreactivities in the caudal trigeminal nucleus of the rat following electrical stimulation of the trigeminal ganglion. Neurosci Lett 261:179-182

32. Morton CR, Hutchison WD (1989) Release of sensory neuropeptides in the spinal cord: studies with calcitonin gene-related peptide and galanin. Neuroscience 31:807-815

33. Schaible HG, Ebersberger A, Peppel P, Beck U, Messlinger K (1997) Release of immunoreactive substance $P$ in the trigeminal brain stem nuclear complex evoked by chemical stimulation of the nasal mucosa and the dura mater encephali-a study with antibody microprobes. Neuroscience $76: 273-284$

34. Morton CR, Hutchison WD (1990) Morphine does not reduce the intraspinal release of calcitonin gene-related peptide in the cat. Neurosci Lett 117:319-324

35. Eftekhari S, Edvinsson L (2011) Calcitonin gene-related peptide (CGRP) and its receptor components in human and rat spinal trigeminal nucleus and spinal cord at C1-level. BMC Neurosci 12:112

36. Pauwels PJ, Tardif S, Palmier C, Wurch T, Colpaert FC (1997) How efficacious are 5-HT1B/D receptor ligands: an answer from GTP gamma $S$ binding studies with stably transfected C6-glial cell lines. Neuropharmacology 36:499-512

37. Hou M, Kanje M, Longmore J, Tajti J, Uddman R, Edvinsson L (2001) 5-HT (1B) and 5-HT(1D) receptors in the human trigeminal ganglion: colocalization with calcitonin gene-related peptide, substance $P$ and nitric oxide synthase. Brain Res 909:112-120

38. Ma QP, Hill R, Sirinathsinghji D (2001) Colocalization of CGRP with 5-HT1B/ $1 \mathrm{D}$ receptors and substance $P$ in trigeminal ganglion neurons in rats. Eur J Neurosci 13:2099-2104 
39. Harriott AM, Scheff NN, Gold MS (2012) The complex actions of sumatriptan on rat dural afferents. Cephalalgia 32:738-749

40. Rocha NF, Rios ER, Carvalho AM, Freire LV, Dias ML, de Franca Fonteles MM, de Sousa FC (2013) Synergistic effect of the L-tryptophan and kynurenic acid with dipyrone or paracetamol in mice. Chem Biol Interact 205:148-156

41. Turski WA, Nakamura M, Todd WP, Carpenter BK, Whetsell WO Jr, Schwarcz $R$ (1988) Identification and quantification of kynurenic acid in human brain tissue. Brain Res 454:164-169

42. Tyce GM (1990) Origin and metabolism of serotonin. J Cardiovasc Pharmacol 16(Suppl 3):S1-S7

43. Wolf $H$ (1974) The effect of hormones and vitamin B6 on urinary excretion of metabolites of the kynurenine pathway. Scand J Clin Lab Invest Suppl 136:1-186

44. Birch PJ, Grossman CJ, Hayes AG (1988) Kynurenate and FG9041 have both competitive and non-competitive antagonist actions at excitatory amino acid receptors. Eur J Pharmacol 151:313-315

45. Knyihar-Csillik E, Toldi J, Krisztin-Peva B, Chadaide Z, Nemeth H, Fenyo R, Vecsei $L$ (2007) Prevention of electrical stimulation-induced increase of $c$-fos immunoreaction in the caudal trigeminal nucleus by kynurenine combined with probenecid. Neurosci Lett 418:122-126

46. Knyihar-Csillik E, Mihaly A, Krisztin-Peva B, Robotka H, Szatmari I, Fulop F, Toldi J, Csillik B, Vecsei L (2008) The kynurenate analog SZR-72 prevents the nitroglycerol-induced increase of $\mathrm{c}$-fos immunoreactivity in the rat caudal trigeminal nucleus: comparative studies of the effects of SZR-72 and kynurenic acid. Neurosci Res 61:429-432

47. Vamos E, Fejes A, Koch J, Tajti J, Fulop F, Toldi J, Pardutz A, Vecsei L (2010) Kynurenate derivative attenuates the nitroglycerin-induced CamKIlalpha and CGRP expression changes. Headache 50:834-843

48. Sang CN, Ramadan NM, Wallihan RG, Chappell AS, Freitag FG, Smith TR, Silberstein SD, Johnson KW, Phebus LA, Bleakman D, Ornstein PL, Arnold B, Tepper SJ, Vandenhende F (2004) LY293558, a novel AMPA/GluR5 antagonist, is efficacious and well-tolerated in acute migraine. Cephalalgia 24:596-602

49. Tallaksen-Greene SJ, Young AB, Penney JB, Beitz AJ (1992) Excitatory amino acid binding sites in the trigeminal principal sensory and spinal trigeminal nuclei of the rat. Neurosci Lett 141:79-83

50. Shigemoto R, Ohishi H, Nakanishi S, Mizuno N (1992) Expression of the mRNA for the rat NMDA receptor (NMDAR1) in the sensory and autonomic ganglion neurons. Neurosci Lett 144:229-232

51. Wang MW, Kumar U, Dong XD, Cairns BE (2012) Expression of NMDA and oestrogen receptors by trigeminal ganglion neurons that innervate the rat temporalis muscle. Chin J Dent Res 15:89-97

52. Lee J, Ro JY (2007) Differential regulation of glutamate receptors in trigeminal ganglia following masseter inflammation. Neurosci Lett 421:91-95

53. Sahara Y, Noro N, lida Y, Soma K, Nakamura Y (1997) Glutamate receptor subunits GluR5 and KA-2 are coexpressed in rat trigeminal ganglion neurons. J Neurosci 17:6611-6620

54. Kung LH, Gong K, Adedoyin M, Ng J, Bhargava A, Ohara PT, Jasmin L (2013) Evidence for glutamate as a neuroglial transmitter within sensory ganglia. PLoS One 8:e68312

55. Lee J, Chung MK, Ro JY (2012) Activation of NMDA receptors leads to phosphorylation of TRPV1 $\mathrm{S} 800$ by protein kinase $\mathrm{C}$ and A-Kinase anchoring protein 150 in rat trigeminal ganglia. Biochem Biophys Res Commun 424:358-363

56. Song JH, Park ES, Han SM, Han SR, Ahn DK, Youn DH (2009) Signal transduction mechanisms underlying group I mGluR-mediated increase in frequency and amplitude of spontaneous EPSCs in the spinal trigeminal subnucleus oralis of the rat. Mol Pain 5:50

57. Hilmas C, Pereira EF, Alkondon M, Rassoulpour A, Schwarcz R, Albuquerque EX (2001) The brain metabolite kynurenic acid inhibits alpha7 nicotinic receptor activity and increases non-alpha7 nicotinic receptor expression: physiopathological implications. J Neurosci 21:7463-7473

58. Liu L, Chang GQ, Jiao YQ, Simon SA (1998) Neuronal nicotinic acetylcholine receptors in rat trigeminal ganglia. Brain Res 809:238-245

59. Ohshiro H, Tonai-Kachi H, Ichikawa K (2008) GPR35 is a functional receptor in rat dorsal root ganglion neurons. Biochem Biophys Res Commun 365:344-348
60. Wang J, Simonavicius N, Wu X, Swaminath G, Reagan J, Tian H, Ling L (2006) Kynurenic acid as a ligand for orphan $\mathrm{G}$ protein-coupled receptor GPR35. J Biol Chem 281:22021-22028

61. Lennerz JK, Rühle V, Ceppa EP, Neuhuber WL, Bunnett NW, Grady EF, Messlinger K (2008) Calcitonin receptor-like receptor (CLR), receptor activity-modifying protein 1 (RAMP1), and calcitonin gene-related peptide (CGRP) immunoreactivity in the rat trigeminovascular system: differences between peripheral and central CGRP receptor distribution. J Comp Neurol 507:1277-1299

doi:10.1186/1129-2377-15-7

Cite this article as: Kageneck et al:: Release of CGRP from mouse brainstem slices indicates central inhibitory effect of triptans and kynurenate. The Journal of Headache and Pain 2014 15:7.

\section{Submit your manuscript to a SpringerOpen ${ }^{\circ}$ journal and benefit from:}

- Convenient online submission

- Rigorous peer review

- Immediate publication on acceptance

- Open access: articles freely available online

- High visibility within the field

- Retaining the copyright to your article

Submit your next manuscript at $\gg$ springeropen.com 